www.jmscr.igmpublication.org

Impact Factor 5.84

Index Copernicus Value: 71.58

ISSN (e)-2347-176x ISSN (p) 2455-0450

crossref DOI: _https://dx.doi.org/10.18535/jmscr/v5i11.119

Journal Of Medical Science And Clinical Research

IGM Publication

An Official Publication of IGM Publication

\title{
Prevalence of Prehypertension and Hypertension among Adult Patients in Kathmandu Medical College and Teaching Hospital, Duwakot, Bhaktapur
}

\author{
Authors \\ Dr Chandra Kala Rai, Dr Prabin Kumar Karki, Dr Biju Shrestha, \\ Prof. Dr Rani Gupta \\ Department of Physiology, Kathmandu Medical College and Teaching Hospital, Bhaktapur, Nepal \\ Corresponding Author \\ Dr Chandra Kala Rai \\ Kathmandu Medical College and Teaching Hospital, Bhaktapur, Nepal \\ Contact No. 977-9841380032, Fax No.977-01-6616568 \\ Email: drchandrak79@gmail.com
}

\begin{abstract}
Introduction: In recent years, one of the global health burden is increased blood pressure, hypertension. It is a condition of sustained increase in blood pressure. Prehypertension is a condition of slight increase in normal blood pressure. So, it is a warning sign that develop hypertension in future. If it is diagnosed on time, hypertension can be prevented by modifying lifestyle.

Aim and Objectives: To determine the prevalence of prehypertension and hypertension in adult patients in Kathmandu Medical College, Duwakot, Bhaktapur, Nepal.

Materials and Methods: This is a cross sectional study done in 350 patients at Kathmandu Medical College and Teaching Hospital, Duwakot, Bhaktapur from march 2017 to July 2017. Blood pressure was measured two times by standard mercury sphygmomanometer and mean was calculated for accuracy. Weight was measured by standard weight scale in kilogram $(\mathrm{kg})$ and height was measured by nonstretchable measuring tape in meter. BMI was calculated by using formula weight in $\mathrm{kg}$ divided by height in $m^{2}$.
\end{abstract}

Results: Prevalence of prehypertension and stage1 hypertension were found maximum $32.66 \%$ and $12(3.43 \%)$ respectively even in young (18-27 years) age with normal BMI. Stage 2 hypertension was maximum 4(1.14\%) with increased age. Stage 2 hypertension was not seen in 18-27 years age group. $P=<0.005$ was considered highly significant. There was statistically highly significant association of hypertension with increase age and BMI $(P=<0.000)$.

Conclusion: Prehypertension was common in young age with normal BMI but stage 1 and stage 2 hypertension increased with increase age and BMI.

Keywords: BMI (Body Mass Index), Hypertension, Prehypertension.

\section{Introduction}

Todays, one of the burning problem of the world is hypertension along with its complications. This is the third leading cause of death in the world. ${ }^{1}$ Hypertension is a condition of sustained increased in blood pressure. Excess weight gain and obesity 
are the leading cause of hypertension $(65-75 \%){ }^{2}$ According to JNC 8, normal blood pressure is systolic 90-119 mm of $\mathrm{Hg}$ and diastolic 60-79 $\mathrm{mm}$ of $\mathrm{Hg}$. Hypertension is a condition where systolic pressure is $>120 \mathrm{~mm}$ of $\mathrm{Hg}$ and diastolic is $>80 \mathrm{~mm}$ of $\mathrm{Hg}$.

Prehypertension (high normal), systolic blood pressure is $120-139 \mathrm{~mm}$ of $\mathrm{Hg}$ and diastolic is 80 $89 \mathrm{~mm}$ of $\mathrm{Hg}$. In stage 1 hypertension, systolic blood pressure is $140-159 \mathrm{~mm}$ of $\mathrm{Hg}$ and diastolic is $90-99 \mathrm{~mm}$ of $\mathrm{Hg}$. In stage 2 hypertension, systolic blood pressure is $160-179 \mathrm{~mm}$ of $\mathrm{Hg}$ and diastolic is $100-109 \mathrm{~mm}$ of $\mathrm{Hg}$. In stage 3 hypertension (hypertensive emergency), systolic pressure is $\geq 180 \mathrm{~mm}$ of $\mathrm{Hg}$ and diastolic is $\geq 110$ $\mathrm{mm}$ of $\mathrm{Hg}$. Isolated systolic hypertension $\geq 140$ $\mathrm{mm}$ of $\mathrm{Hg}$ and diastolic $<90 .{ }^{3}$

Most of the time the prehypertension condition is asymptomatic. But, it is a warning stage of hypertension. Early diagnosis has very important value to prevent hypertension by modifying lifestyle. The extremely elevated blood pressure shows features of headache, fatigue or dizziness and visual changes. ${ }^{4}$

Many factors are responsible to cause hypertension like smoking, obesity, sedentary lifestyle, old age, stress, genetic factor, family history, systemic diseases and consumption of salty and fatty foods. ${ }^{5}$

\section{Materials and Methods}

This is a cross sectional study done in Kathmandu Medical College and Teaching Hospital, Duwakot, Bhaktapur from march 2017 to July 2017. Approval for research was taken from Institutional research committee (IRC).

All the OPD and ward patients were taken from Kathmandu Medical College and Teaching Hospital, Duwakot by random sampling. Verbal and written consent of the participants were taken. All the cases were screened which include through history and examination as per porforma. Name, age, sex, address and contact no. were recorded. Patient above 18 years were included where patient with chronic disease, malignancy and pregnant were excluded.

The blood pressure was measured by mercury sphygmomanometer for two times and mean was calculated for accuracy. The subject already diagnosed to have hypertension and under antihypertensive medication was also considered being hypertensive. Patients' height in meter was measure by non-stretchable measuring tape and weight in kilogram $(\mathrm{kg})$ were measured by weight scale to calculate BMI. The formula weight in $\mathrm{kg}$ was divided by height in meter square was used to calculate the BMI of patients and unit is $\mathrm{kg} / \mathrm{m}^{2}$. According to WHO (World Health Organization), "Asian Criteria" for BMI cut off point are less than 18.5 is underweight,18.5-22.9 is normal, 2324.9 is overweight, $25-29.9$ is pre-obese, $\geq 30$ obese, 30-40 type 1 obese, 40.1-50 type 2 obese and more than 50 is type 3 or super obese.

Collected data were compiled and analyzed by using Statistical Package of Social Science (SPSS) software version 16. Chi-square test was used to find group association. P-value of $<0.005$ was considered to be highly significant.

\section{Results}

Total number of patients were 350 . The mean age of patients' was 29.49 and standard deviation was \pm 14.78 .

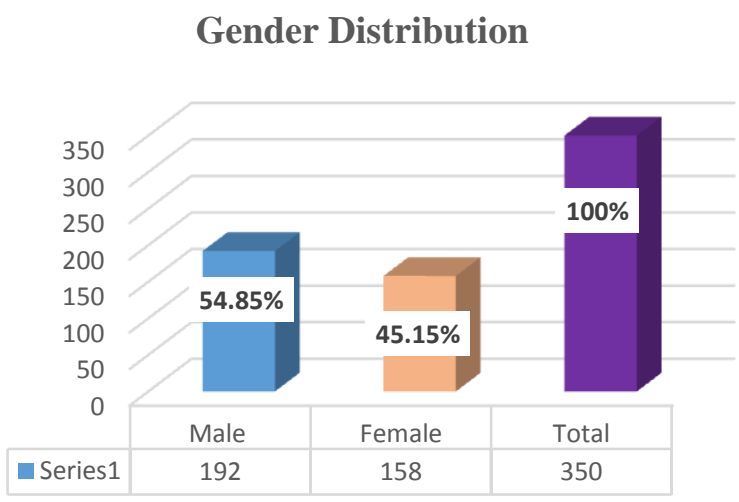

Figure 1. Gender distribution in total number of patients.

In total, $192(54.85 \%)$ were male and 158 $(45.15 \%)$ were female 


\section{JMSCR Vol||05||Issue||11||Page 30509-30514||November}

Table 1. Distribution of systolic and diastolicblood pressure in different age groups.

Systolic blood pressure

\begin{tabular}{|c|c|c|c|c|c|c|}
\hline $\begin{array}{l}\text { Age in } \\
\text { years }\end{array}$ & $\begin{array}{l}\text { Normal } \\
(90-119 / \\
60-79)\end{array}$ & $\begin{array}{c}\text { Prehypertension } \\
(120-139 / \\
80-89)\end{array}$ & $\begin{array}{c}\text { Stage } 1 \text { HTN } \\
(140-159 / \\
90-99)\end{array}$ & $\begin{array}{c}\text { Stage } 2 \text { HTN } \\
(160-179 / \\
100-109)\end{array}$ & Total & $\begin{array}{l}\text { Chi } \\
\text { square } \\
\text { test }\end{array}$ \\
\hline $18-27$ & $107(30.57 \%)$ & $113(32.28 \%)$ & $3(0.87 \%)$ & $0(0.0 \%)$ & $223(63.7 \%)$ & \\
\hline $28-37$ & $14(4.0 \%)$ & $32(9.14 \%)$ & $7(2 \%)$ & $0(0.0 \%)$ & $53(15.1 \%)$ & \\
\hline $38-47$ & $4(1.14 \%)$ & $21(6 \%)$ & $3(0.85 \%)$ & $0(0.0 \%)$ & $28(8.0 \%)$ & \\
\hline $48-57$ & $5(1.42 \%)$ & $7(3.93 \%)$ & $6(1.71 \%)$ & $1(0.28 \%)$ & $19(5.4 \%)$ & \\
\hline $58-67$ & $3(0.85 \%)$ & $4(1.14 \%)$ & $9(2.57)$ & $0(0.0 \%)$ & $16(4.6 \%)$ & 0.00 \\
\hline $68-77$ & $4(1.14 \%)$ & $1(0.28 \%)$ & $3(0.85 \%)$ & $0(0.0 \%)$ & $8(2.3 \%)$ & \\
\hline $78-87$ & $0(0.0 \%)$ & $0(0.0 \%)$ & $0(0.0 \%)$ & $0(0.0 \%)$ & $0(0.0 \%)$ & \\
\hline $87-97$ & $0(0.0 \%)$ & $0(0.0 \%)$ & $3(0.85 \%)$ & $0(0.0 \%)$ & $3(0.9 \%)$ & \\
\hline Total & $137(39.14 \%)$ & $178(50.85 \%)$ & $34(9.71 \%)$ & $1(0.28 \%)$ & $350(100 \%)$ & \\
\hline
\end{tabular}

Diastolic Blood Pressure

\begin{tabular}{|lccccc|c|}
\hline $\begin{array}{l}\text { Age in } \\
\text { years }\end{array}$ & $\begin{array}{c}\text { Normal } \\
(90-119 /\end{array}$ & $\begin{array}{c}\text { Prehypertension } \\
(120-139 /\end{array}$ & $\begin{array}{c}\text { Stage 1 HTN } \\
(140-159 /\end{array}$ & $\begin{array}{c}\text { Stage 2 HTN } \\
(160-179 /\end{array}$ & $\begin{array}{c}\text { Chi - } \\
\text { square } \\
\text { test }\end{array}$ \\
\hline $18-27$ & $96(27.50 \%)$ & $114(32.66 \%)$ & $12(3.43 \%)$ & $0(0.0 \%)$ & $222(63.6 \%)$ & \\
\hline $28-37$ & $26(7.44 \%)$ & $19(5.44 \%)$ & $7(2.0 \%)$ & $1(0.28 \%)$ & $53(15.2 \%)$ \\
\hline $38-47$ & $12(3.43 \%)$ & $13(3.72 \%)$ & $2(0.57 \%)$ & $1(0.28 \%)$ & $28(8.0 \%)$ \\
\hline $48-57$ & $5(1.43 \%)$ & $4(1.14 \%)$ & $9(2.57 \%)$ & $1(0.28 \%)$ & $19(5.4 \%)$ & 0.00 \\
\hline $58-67$ & $9(2.57 \%)$ & $1(0.28 \%)$ & $6(1.71 \%)$ & $0(0.0 \%)$ & $16(4.6 \%)$ & $8(2.3 \%)$ \\
\hline $68-77$ & $2(0.57 \%)$ & $1(0.28 \%)$ & $5(1.43 \%)$ & $0(0.0 \%)$ & $0(0.0 \%)$ \\
\hline $78-87$ & $0(0.0 \%)$ & $0(0.0 \%)$ & $0(0.0 \%)$ & $0(0.0 \%)$ & $3(0.9 \%)$ \\
\hline $87-97$ & $0(0.0 \%)$ & $2(0.6 \%)$ & $0(0.0 \%)$ & $1(0.3 \%)$ & $350(100 \%)$ \\
\hline Total & $150(42.97 \%)$ & $154(44.12 \%)$ & $41(11.74 \%)$ & $4(1.14 \%)$ & & \\
\hline
\end{tabular}

In total, maximum 96(27.50\%) patients with age group 18-27 years were healthy. Prehypertension with increase SBP (Systolic Blood Pressure) was maximum in young person $113(32.28 \%)$, DBP (Diastolic Blood Pressure) 114(32.66\%) with age group 18-27 years. Rate of prehypertension decrease with increase in age but developed stage 1 and stage 2 hypertension. Stage 1 hypertension with maximum SBP was $2.57 \%$ in age 58-67 years, where DBP was $2.57 \%$ at age $48-57$ years. Stage 2 hypertension with increased SBP was present with 48-57 years and DBP 4(1.14\%) with increased age. $\mathrm{P}=<0.005$ is considered highly significant. This study showed highly significant $(\mathrm{P}=0.00)$ association of age and hypertension.

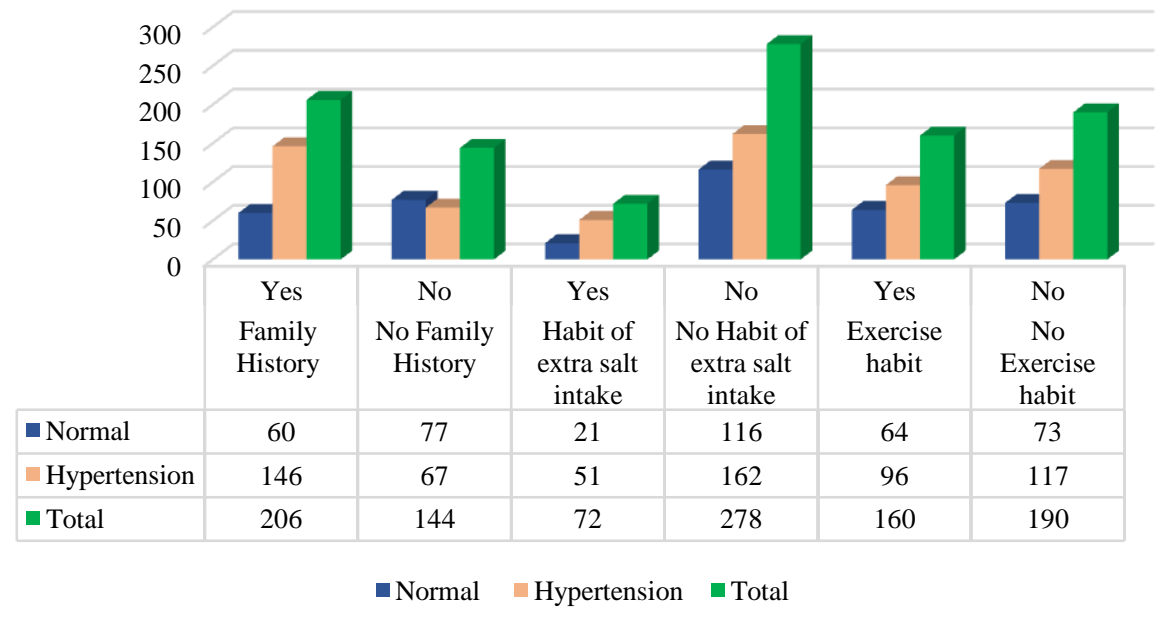

Figure 2. Demographic characteristic in relation to blood pressure. 


\section{JMSCR Vol||05||Issue||11||Page 30509-30514||November}

Patients with family history showed highly significant $(\mathrm{p}=0.00)$ relation with hypertension. Among 206 patients with family history, 146 had hypertension. In total 144 patients without family history, 67 had hypertension. The patients who had habit of extra salt intake had more incidence of hypertension but it is insignificant $(\mathrm{p}=0.218)$. The patients without exercise habits used to develop hypertension than with exercise. But it was associated insignificantly $(\mathrm{p}=0.513)$.

Table 2. Distribution of systolic and diastolic blood pressure of patients according to different BMI categories

\begin{tabular}{|c|c|c|c|c|c|c|}
\hline \multirow[b]{2}{*}{$\begin{array}{l}\text { Body } \\
\text { Mass } \\
\text { Index } \\
\left(\mathrm{kg} / \mathrm{m}^{2}\right)\end{array}$} & \multicolumn{5}{|c|}{ Systolic Pressure } & \multirow{2}{*}{$\begin{array}{c}\text { Chi-square } \\
\text { test } \\
(\mathrm{p}=<0.005)\end{array}$} \\
\hline & $\begin{array}{l}\text { Normal } \\
(90-119 / \\
60-79)\end{array}$ & $\begin{array}{c}\text { Pre- } \\
\text { hypertension } \\
(120-139 / \\
80-89)\end{array}$ & $\begin{array}{c}\text { Stage 1 } \\
\text { hypertension } \\
(140-159 / \\
90-99)\end{array}$ & $\begin{array}{c}\text { Stage } 2 \\
\text { hypertension } \\
(160-179 / \\
100-109)\end{array}$ & Total & \\
\hline $\begin{array}{l}\text { Underweight } \\
<18.5)\end{array}$ & $16(4.6 \%)$ & $6(1.7 \%)$ & $0(0 \%)$ & $0(0.0 \%)$ & $22(6.3 \%)$ & \multirow{6}{*}{0.00} \\
\hline $\begin{array}{l}\text { Normal } \\
(18.5-22.9)\end{array}$ & $80(22.9 \%)$ & $66(18.9 \%)$ & $6(1.7 \%)$ & $0(0.0 \%)$ & $152(43.4 \%)$ & \\
\hline $\begin{array}{l}\text { Overweight } \\
(23-24.9)\end{array}$ & $13(3.7 \%)$ & $43(12.3 \%)$ & $2(0.6 \%)$ & $0(0.0 \%)$ & $58(16.6 \%)$ & \\
\hline $\begin{array}{l}\text { Pre-obese } \\
(25-29.9)\end{array}$ & $23(6.6 \%)$ & $51(14.6 \%)$ & $17(4.9 \%)$ & $1(0.3 \%)$ & $92(26.3 \%)$ & \\
\hline $\begin{array}{l}\text { Obese } \\
(\geq 30)\end{array}$ & $5(1.4 \%)$ & $12(3.4 \%)$ & $9(2.6 \%)$ & $0(0.0 \%)$ & $26(7.4 \%)$ & \\
\hline Total & $137(39.1 \%)$ & $178(50.9 \%)$ & $34(9.7 \%)$ & $1(0.3 \%)$ & $350(100 \%)$ & \\
\hline
\end{tabular}

\begin{tabular}{|l|l|l|l|l|l|l|}
\hline & \multicolumn{5}{|c|}{ Diastolic Pressure } & \multirow{2}{*}{ Significance } \\
\cline { 2 - 6 } $\begin{array}{l}\text { Body Mass } \\
\text { Index }\end{array}$ & $\begin{array}{l}\text { Normal } \\
(90-119 / \\
60-79)\end{array}$ & $\begin{array}{l}\text { Pre- } \\
\text { hypertension(1 } \\
20-139 / \\
80-89)\end{array}$ & $\begin{array}{l}\text { Stage } \\
\text { hypertension(14 } \\
0-159 / \\
90-99)\end{array}$ & $\begin{array}{l}\text { Stage } \\
\text { hypertension(1 } \\
60-179 / \\
100-109)\end{array}$ & Total & (p=<0.005) \\
\hline $\begin{array}{l}\text { Underweight } \\
(<18.5)\end{array}$ & $14(4.0 \%)$ & $8(2.3 \%)$ & $0(0 \%)$ & $0(0.0 \%)$ & $22(6.3 \%)$ & \\
\hline $\begin{array}{l}\text { Normal } \\
(18.5-22.9)\end{array}$ & $80(22.9 \%)$ & $66(18.9 \%)$ & $6(1.7 \%)$ & $0(0.0 \%)$ & $152(43.4 \%)$ & \\
\hline $\begin{array}{l}\text { Overweight } \\
(23-24.9)\end{array}$ & $22(6.3 \%)$ & $35(10 \%)$ & $1(0.3 \%)$ & $0(0.0 \%)$ & $58(16.6 \%)$ & \multirow{2}{*}{0.00} \\
\hline $\begin{array}{l}\text { Pre-obese } \\
(25-29.9)\end{array}$ & $28(8.0 \%)$ & $39(11.2 \%)$ & $23(6.6 \%)$ & $2(0.6 \%)$ & $92(26.3 \%)$ & \\
\hline $\begin{array}{l}\text { Obese } \\
(\geq 30)\end{array}$ & $7(2.0 \%)$ & $6(1.7 \%)$ & $11(3.2 \%)$ & $2(0.6 \%)$ & $26(7.4 \%)$ & \\
\hline Total & $137(39.1 \%)$ & $154(44.1 \%)$ & $41(11.7 \%)$ & $4(1.1 \%)$ & $350(100 \%)$ & \\
\hline
\end{tabular}

As assessed by SBP and DBP, maximum percentage of prehypertension was found in the person with normal BMI, SBP and DBP were $18.9 \%$. Similarly, pre-obese patients had Stage I hypertension with SBP $4.9 \%$ and DBP 23(6.6\%). Stage 2 hypertension was found in pre-obese and obese patients but not in underweight, normal and overweight person.
It showed increase in BMI was statistically highly significant (chi-square $P<0.000$ ) with increase in severity of hypertension. The underweight patients were less likely to have hypertension.

\section{Discussion}

Nowadays, the most important public health challenge in the world is hypertension. Many 
studies had shown that prevalence of hypertension is increasing in developing country like in Nepal. The main purpose and aim of this study is to find out the prevalence of prehypertension and hypertension to the adult patients coming to Kathmandu Medical College and Teaching Hospital, Duwakot, Bhaktapur, Nepal.

A study done by Vaidya A et.al on "Exploring the iceberg of hypertension: a community based study in an eastern Nepal" in 2004 to 2005. This study showed that prevalence of hypertension was $22.7 \%$ in total studied population ${ }^{5}$. This current study showed the prevalence of hypertension is much higher than previous study. About $44.12 \%$ have prehypertension and $11.74 \%$ have stage 1 hypertension and $1.14 \%$ have stage 2 hypertension. In total, $57 \%$ of patients have hypertension. ${ }^{6}$

Similar study was done in Bhadrabas in 2006 by Vaidya A, the study showed prevalence of hypertension was $33.8 \%$ of total sample. ${ }^{7}$

Another similar study was done by Suman Dua in 2014, the study co-related the relationship between hypertension and BMI. They found rate of hypertension was 8.98 times higher with high BMI person. The underweight patients were less likely to have hypertension. In current study, the rate and severity of hypertension is increased with increase in BMI. ${ }^{8}$

NK Sainju also observed rate of prehypertension and hypertension in Kathmandu Medical College students. This study showed about $23.3 \%$ had prehypertension or hypertension. There was statistically significant $(\mathrm{p}=0.008)$ association between BMI and hypertension. Life style variables were not associated with hypertension ( $p>0.05)$. In current study, there is significant relation with family history but exercise, extra salt intake habit are associated insignificantly. ${ }^{9}$

A study was done in Kathmandu in 2005, this study showed prevalence of hypertension was $19.7 \% .^{10}$

In North Karelia, a study was done to observe hypertension care in 10 years period from 19721982. The awareness of hypertension increased from $39 \%$ to $71 \%$ among male and from $60 \%$ to
$87 \%$ among female. The level of increased blood pressure was also controlled. So, proper care can control the level of blood pressure. ${ }^{11}$

A study was done in sodium-potassium level and mortality rate. The amount of sodium consumption was directly associated with increased in blood pressure and mortality rate. But current study shows insignificant association of salt intake and hypertension. ${ }^{12}$

A community-based cross-sectional study conducted in the municipalities of Kathmandu District, Nepal, in 2015 showed prevalence of hypertension was $32.5 \%$. Gender, age education, ethnicity, occupation, alcohol consumption, smoking, exercise habit, diabetes, menopausal and family history were significantly associated with hypertension. ${ }^{13}$

A cross-sectional study was conducted in April 2012 in Gondar city, North-West Ethiopia to determine the prevalence and associated factors of hypertension among adults. About 28.3\% had hypertension and family history, obesity, diabetes and sedentary life style were directly related with hypertension. ${ }^{14}$ Similar result $(29.1 \%)$ was seen in a study of USA. ${ }^{15}$

Research done in 1980 to 2002 showed prevalence of hypertension $26.4 \%$. This study projected increasing rate of hypertension. It predicted the rate of hypertension to increase up to $60 \%$ of total population by $2025 .^{16}$

\section{Conclusion}

Present study showed that prevalence of hypertension is maximum in young age with normal BMI. But the stage 1 and stage 2 hypertension was increased with age and BMI. So, current study showed highly significant association of hypertension with age and BMI.

\section{References}

1. Stephen SL, Theo V, Abraham DF et.al. A comparative risk assessment of burden of disease and injury attributable to 67 risk factors and risk factor clusters in 21 regions, 1990-2010: a systematic analysis 
for the Global Burden of Disease Study 2010. Lancet. 2012 Dec 15; 380(9859): 2224-2260.

2. Guyton AC. Role of the Kidneys in LongTerm Control of Arterial Pressure and in Hypertension. Guyton AC, Hall JE, editors. Guyton and Hall Textbook of Medical Physiology. $12^{\text {th }}$ ed. Philadelphia: WB Saunders Inc:2000.p.225.

3. JNC 8 Guidelines for the Management of Hypertension in Adults.Am Fam Physician. 2014 Oct 1;90(7):503-504.

4. James PA, Oparil S, Carter BL, Cushman WC, DennisonHC, Handler J. et al. 2014 evidence-based guideline for the management of high blood pressure in adults: report from the panel members appointed to the Eighth Joint National Committee (JNC 8) JAMA 2014;311 (17):1809] JAMA. 2014;311(5):507-20.

5. Kayee B, June T, Bernie R. Hypertension: The silent killer: Updated JNC-8. Guideline Recommendations. June 1, 2015.

6. Vaidya A, Pokharel PK, Karki P, Nagesh S. Exploring the iceberg of hypertension: a community based study in an eastern Nepal town. Kathmandu Univ Med J (KUMJ). 2007 Jul-Sep;5(3):349-59.

7. Vaidya A, Pathak RJ, Pandey MR. Prevalence of hypertension in Nepalese community triples in 25 years: a repeat cross-sectional study in rural Kathmandu. Indian Heart J. 2012 Mar; 64(2): 128-131.

8. Dua S, Bhuker M, Sharma P, Dhall M, and Kapoor S. Body Mass Index Relates to Blood Pressure Among Adults. N Am J Med Sci. 2014 Feb; 6(2): 89-95.

9. Sainju NK. The prevalence of hypertension and pre hypertension. Webmedcentral ISSN 2046-1690.16 Jul 2015 02:52:26 PM GMT.

10. Sharma D, Bkc M, Rajbhandari S, Raut R, Baidya SG, Kafle PM, Baral B, Rajbhandari R, Bhatt YD, Malla R, Maskey A, Limbu Y, Regmi SR, Koirala B. Study of Prevalence, Awareness, and control of Hypertension in a Suburban Area of Kathmandu, Nepal. Indian Heart J. 2006 Jan-Feb;58(1):34-7.

11. Nissinen A, Tuomilehto J, Korhonen HJ, Piha T, Salonen JT, PuskaP.Ten-year results of hypertension care in the community. Follow-up of the North Karelia hypertension control program. Am J Epidemiol. 1988 Mar;127(3):488-99.

12. Yang Q, Liu T, Kuklina EV, Flanders WD, Hong Y, Gillespie C, Chang MH, Gwinn M, Dowling N, Khoury MJ, Hu FB. Sodium and potassium intake and mortality among US adults: prospective data from the Third National Health and Nutrition Examination Survey. Arch Intern Med. 2011 Jul 11; 171(13):1183-91.

13. Dhungana RR, Pandey AR, Bista B, Joshi S, Devkota S. Prevalence and Associated Factors of Hypertension: A Community-Based Cross-Sectional Study in Municipalities of Kathmandu, Nepal. International Journal of Hypertension Volume 2016 (2016), Article ID 1656938, 10 pages. http://dx.doi.org/10.1155/2016/1656938

14. Awoke, A, Awoke, T, Alemu S,Megabiaw B. Prevalence and associated factors of hypertension among adults in Gondar, Northwest Ethiopia: A community based cross-sectional study. BMC Cardiovascular Disorders. Volume 12, 28 November 2012, Article number 113.

15. Nwankwo A, Sung S, Burt V, Qiuping G. Hypertension Among Adults in the United States: National Health and Nutrition Examination Survey, 2011-2012. NCHS Data Brief No. 133, October 2013.

16. Patricia MK, Megan W, Kristi R, Paul M, Paul K W. Global burden of hypertension: analysis of worldwide data DOI: http://dx.doi.org/10.1016/S01406736(05)17741-1. 